\title{
Designing Playgrounds for All
}

\author{
Herkes Için Çocuk Parkları Tasarlamak
}

Aslı SUNGUR, Patrycja CZAPLINSKA

\section{ABSTRACT}

Cities, streets, buildings and playgrounds transform and evolve in time. These places are public spaces and should be available for every user, being a place suited for everybody, not excluding the disabled. Cities, being immediate surroundings, have a huge effect on the residents' lives. The effect of environment on differently abled children, who not only has to survive through challenges of their disability but also in the process of a continuous development, is even greater. Being disabled as a child shouldn't mean to be excluded from the group of peers which have a great role in the physical and the psychological development of the child. This paper is describing several types of disabilities and the effect of environment on children with these disabilities. Problems of children with sight loss, reduced mobility, hearing problems and different intellectual abilities are described. It is indisputable, that these children need much attention. Being a part of the social group can help them in developing their communication and physical skills by playing or just spending time with others. In the paper, characteristic of a common playground which is a public space designed for children has been made. The equipment and the material of the "a playground for all" are described. Designing and material considerations are made and the ground, playground equipment, materials and colors and level differences are characterized. The aim of this paper is to lead a way for the designer to build a place for the children which will be fully accessible for every child.

Keywords: Accessible playground; disabled children; playground for all.

ÖZ

Şehirler, sokaklar, yapılar ve parklar zaman içinde değişip gelişirler. Bu alanlar kamusal alanlar olmaları sebebiyle, engelli bireyleri dışarıda bırakmadan, herkes için rahatça kullanılabilir olmalıdırlar. Şehirler, şehir sakinlerinin yakın çevresi konumunda olduklarından, etkileri de inkar edilemez derecede büyük olmaktadır. Bu etki, aynı zamanda hayatını çeşitli kısıtılıklarla sürdürmek zorunda ve henüz yetişkinliğe adım atmamış, gelişme çağındaki çocuklarda daha da fazla görülmektedir. Bir engele sahip olmak, çocuk için, gerek fiziksel gerekse psikolojik gelişiminde büyük yere sahip olan arkadaş çevresinden uzaklaşmak anlamına gelmemelidir. Makalede, çeşitli engel türleri, bu engellerin çevre aracılığıla çocuklar üzerindeki etkilerine odaklanılarak anlatılmaktadır. Görme kaybı, hareket kısıtılığı, duyma sorunları yaşayan ve farklı bilişsel ve algısal yeterlilikteki çocukların sorunları tarif edilmektedir. Bu çocukların, daha fazla ilgi ve dikkate ihtiyaç duydukları açıktır. Diğer bireylerle vakit geçirerek veya oyun oynayarak bir sosyal grubun parçası olmak ise; fiziksel ve iletişim becerilerini geliştirmelerine yardımcı olabilmektedir. Makalede; kamusal bir alan olan çocuk oyun parklarının genel özellikleri verilmekte, 'herkes için tasarlanmış çocuk parkları́nın tasarım, zemin, malzeme, renk özellikleri ve donatı seçimleri detaylı olarak anlatılmakta ve bazı öneriler sunulmaktadır. Amaç, tasarımcının, her çocuk ve yetişkin için ulaşılabilir çocuk oyun alanları tasarımı sürecine katkıda bulunmaktır.

Anahtar sözcükler: Ulaşılabilir çocuk parkları; engelli çocuklar; herkes için çocuk parkları.

Department of Architecture, Yıldız Technical University Faculty of Architecture, İstanbul, Turkey

Article arrival date: December 29, 2017 - Accepted for publication: April 08, 2016

Correspondence: Aslı SUNGUR. e-mail: asungur@gmail.com

๑ 2018 Yıldız Teknik Üniversitesi Mimarlık Fakültesi - ๑ 2018 Yıldız Technical University, Faculty of Architecture 


\section{Being Disabled As A Child in the World Dedicated to the Healthy People}

In many parts of the world, user's expectations are changing for a better environment. Today, there are higher expectations for access to public services (i.e. park and recreation programs, services, activities and facilities). To the contrary, when public services are inaccessible and fail to meet citizen expectations, the results have led to increased visibility of complaints and litigation where park visitors and program participants have encountered physical and programmatic barriers associated with allegations of discrimination based on disability' (Skulski, 2009).

Unfortunately, when thinking about accessibility, it is common that only adults are thought and disabled children are forgotten. Being a child in adults' world sometimes is hard enough, but with more limitations it can be unenforceable. It is a fact that growing up children are cruel toward others, especially when they are different from them. However, if disabled children are a part of the community from the beginning, others learn that it is normal to spend time together. Being disabled as a child shouldn't mean to be excluded from the group of peers. Spending time together is also important from the point of child's psyche. Communication is one of most relevant fields to develop while adolescence. This step is essential for the proper functioning of the human in his life. Via playing together, children learn to respect the norms and social rules and about tolerance and, explore their creativity.

\section{The Effect of Environment On Differently Abled Children}

If a child is blind or sand-blind he or she doesn't have the ability to know the world by observation. It is highly important to provide them other ways of learning about the world. They need a lot of opportunities to touch, hear and smell the things they are not able to see. Visually impaired children develop properly if the rest of their senses are stimulated accordingly. The only difference that is noticed is that they start talking later than children who can see as says Chris Strickling from Texas School for the Blind and Visually Impaired: 'much of what is learned by the normal child is learned by imitating others. The blind infant may jabber and imitate sooner than a sighted child, but may show delay when combining words to make his wants known.' The blind child primarily uses language to say his immediate needs or to describe current activities. The blind child may take in the sounds which make up the language, but may not grasp the meaning intended by the speaker. His sensory experiences are not readily coded into language. He may store phrases and sentences in his memory and repeat them out of context. The early language of the blind child does not seem to mirror his developing knowledge of the world, but rather his knowledge of the language of others.

It is worth keeping in mind, that when a visually impaired baby starts to crawl or walk, the goal should be to provide them a safe environment instead of forbidding. It is important to avoid passivity and focus on activity, so the children won't live in fear of the unknown space. Their sense of hearing and touching should be stimulated and developed more as a result, given that these will have very big impact on their future lives. Children with reduced mobility also would like to walk, run and climb everywhere just like any other child. Although sometimes it is hard, it doesn't mean it is impossible at least in a certain percentage. For example; if a child has paralyzed legs, but healthy hands, he can use them to pull up during daily routine or to race with friends on the prepared route in a wheelchair. Every child has his or her own needs and we need to try to provide the solutions to these.

The results provide evidence of a general effect of environmental setting on mobility methods of children with cerebral palsy. Compared with their mobility at school, children were more dependent on adult assistance for mobility when outdoors or in the community and less dependent on adult assistance at home. The results are consistent with previous reports that mobility methods of children with CP vary across environmental settings (Palisano R. J., 2003). One can identify not only an object itself, but also the direction and the distance at which it is, with the help to the hear sense. The average efficiency of deaf children in the field of motor skills is smaller than the efficiency of their hearing peers. If there is a damage of inner ear, a child can have a problem with balance and smooth movements.

Coordination in movements needs to be thought by proper physical education. It is important to provide deaf children enhanced opportunities for movement. It can be reached by sports activities, games and other methods of improving the level of general health and physical resistance. Deaf children need to explore the world based on what they see, touch, smell and taste. Compensation of senses is a mechanism than can calm the effects of disability.

Children can be limited not only by their bodies, but also by their intellectual abilities. They may suffer Autism, Down Syndrome or other intellectual disabilities and even a high IQ. These children need to put more effort into their social and communication skills and in other areas of current functioning abilities.

However, not only children with low IQ level but also with high IQ do suffer while growing up. A gifted six-yearold first grader may have reached the level of development (normally reached between the ages of eight and nine) at 
which she especially likes games with complex rules. She plays the simpler games the other six-year-olds like to play on the playground, and then she suggests that they play one of her favorites. The other children refuse. How does she interpret this rejection? Seldom with a sense that she is better than them. She is more likely to think, "They don't like me." And it is a very short step from 'they don't like me' to 'I'm not likable' (Miraca U. M. G., 1998). Taking this into consideration, it is indisputable, that these children need much more contact with the surrounding and peers, as it can be assumed. Being a part of the social group can help children in developing their communication skills by playing or just spending time with others.

\section{Playgrounds for All}

For a child, being outdoors is the only chance for exploring the world surrounds him or her. It is the outdoors where children can freely experience their motor skills like running, jumping, climbing etc. It is also the most appropriate area for performing manipulative skills such as swinging, lifting, and balancing. In most of the cases; outdoors have something more than physical benefits. As children play outdoors, they are more likely to invent games and learn about the world in their own way (Metin P., 2003). The challenge is to find the balance between providing a playground that is safe and one which still provides children with opportunities for active and passive play which they want and need. There is encouraging evidence to show that schools that have set about making their playground a much more interesting and stimulating environment have not only managed to reduce bullying behavior but they have observed the development of a sense of caring and sharing which makes the time expense and effort worthwhile (Evans J., 2001).

Having fun doesn't need to be focused only on developing mobility skills, but also expending senses range and communication abilities. If designer is using non-schematic solutions, than children, can be more creative while playing. When mentioning about designing playgrounds for all, it is essential to mention universal design as well. Rather than focusing on users with specific disabilities, universal design creates solutions that will work for everyone, regardless of age, mobility, visual, auditory or mental ability. (...) Universal design is a holistic concept that can be applied to every product type, but it is especially applicable to buildings and public spaces. Because these spaces get a huge amount of use by a vastly diverse population, a design that is accessible and usable for everyone is crucial (Zimmermann R., 2006) (Figure 1).

An example for "a playground for all" is 'Brooklyn's Playground' located in Idaho. It is an accessible playground built by the local community with the help of volunteers.

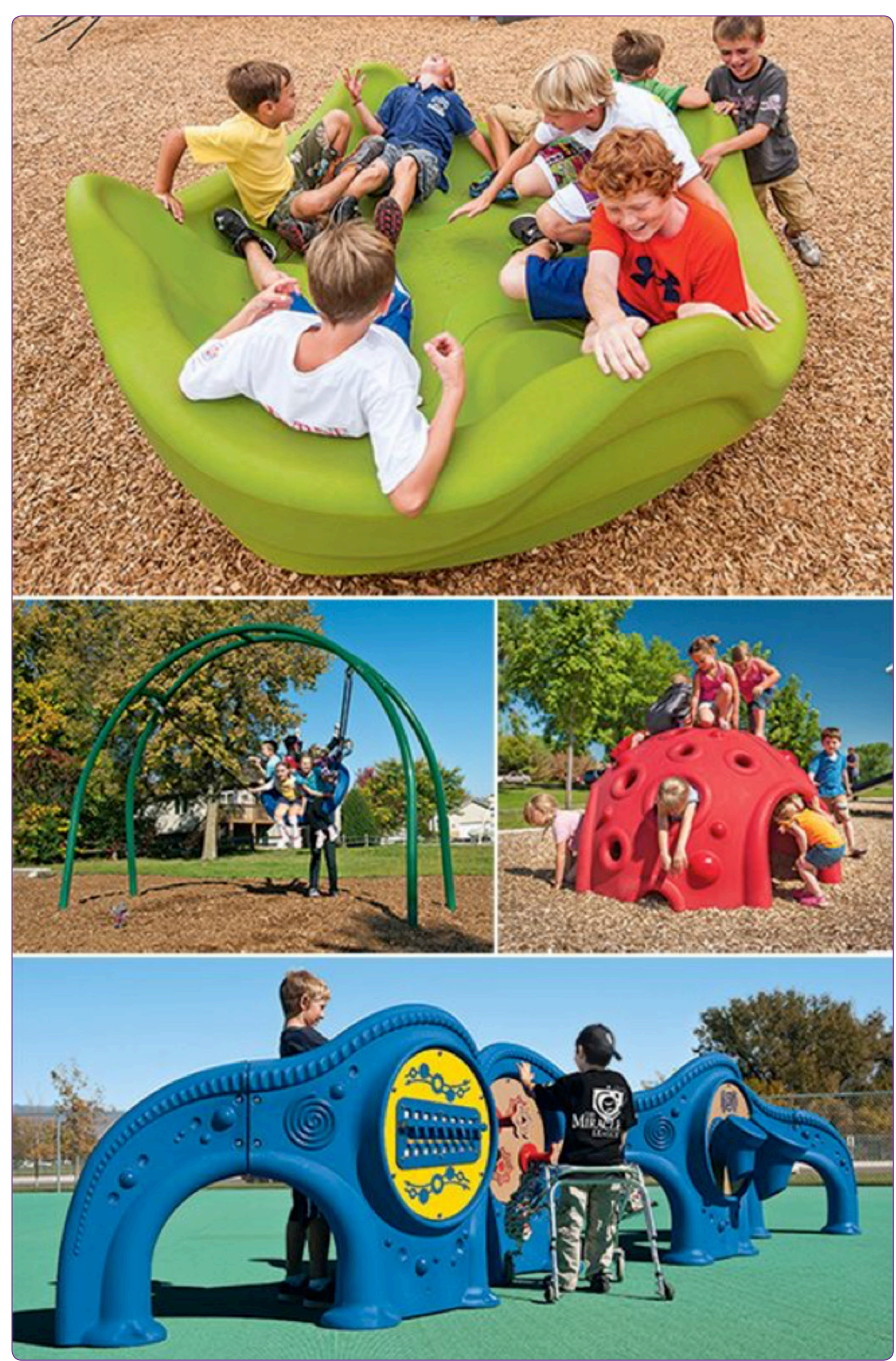

Figure 1. Children playing with each other without any type of discrimination.

The ground is covered with rubberized surface allowing children on the wheelchairs or with the crutches to move freely, without a fear of getting stuck in the muddy ground. At the same time the surface is soft enough to protect children from serious injuries in the case of falling down (Figure 2).

Instead of stairs or ladders, there are wide ramps and wide transition points, which enable easy moving between equipment, for both, children who are running and for the ones who are using wheelchairs. There are also provided maneuvering spaces to prevent the collisions and facilitates comfortable moving.

The height of the equipment was considered upon the reach ranges of children on the wheelchairs which is suitable also for the youngest users of the playground. To get all of the children interested in playing together, the equipment varies in color, shape, height and purpose. The equipment is designed the way, that it is possible always to give new physical challenges to all children and to prevent 


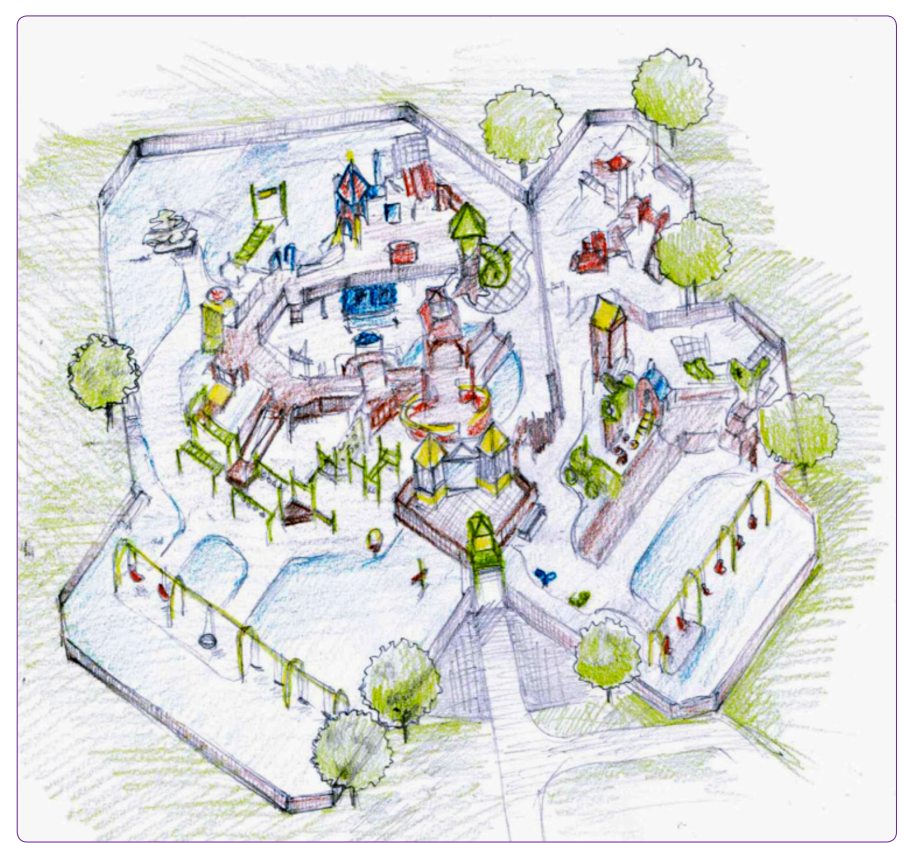

Figure 2. Concept drawing of Brooklyn's Playground. Redrawn from http://brooklynsplayground.org/see-the-playground.

them from boredom. The most important aspect to notice is that not only the ground is suitable for disabled kids, but also the equipment (Figure 3 ).

\section{Designing and Material Considerations of A "Playground For All"}

The role of the playground is not only to provide a place to play but also to learn to live in the society and gain their communication skills. Playground offers the opportunity to develop physical skills and increases the efficiency of the senses. It cannot be denied, that disabled children need more protection and more specialized equipment to be able to play with others. However, children who are considered as "healthy" benefit from these facilities as well.

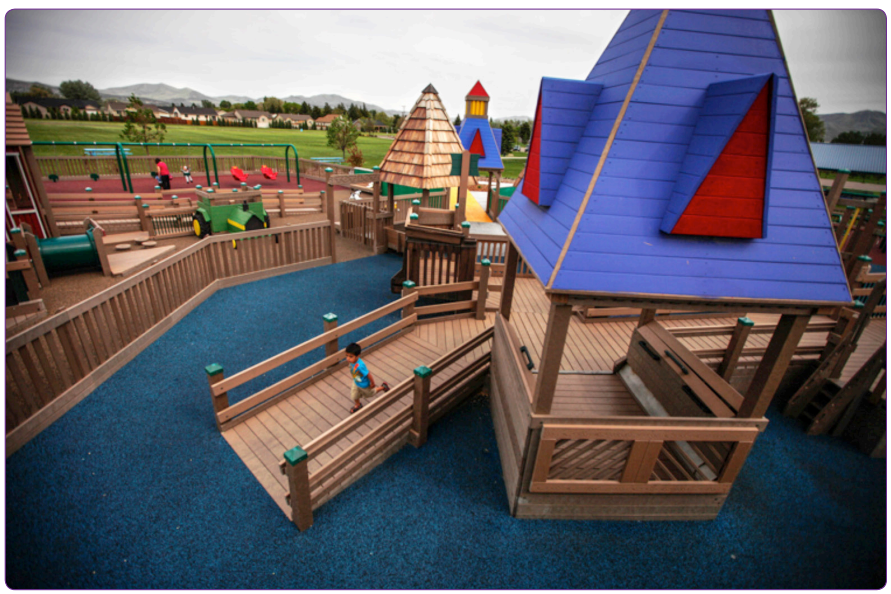

Figure 3. Wide ramps allow children of all abilities easy access to all of the parts of Brooklyn's Playground.

\section{Ground}

The ground is an important issue while designing a playground, sometimes it is even crucial. Safe ground characterizes with good shock absorbance parameters. A safe ground material can help in most injuries caused by falling down. Concrete, asphalt, or other hard surfaces should never be directly under playground equipment. Grass and dirt are not considered protective surfacing because environmental factors can reduce their shock absorbing effectiveness (Consumer Product Safety Commission, 2010).

However, taking into consideration the flooring, one needs to think about all of the children, healthy and disabled. Even if wood chips seems to be the best choice, the wheel of the wheelchair can stuck in it easily. While deciding of the ground cover, it is needed, all advantages and disadvantages to be taken into consideration. Below is the table (Table 1) for the possible ground materials and their properties (Figure 4).

While designing a fully accessible playground, the ground needs to be solid, otherwise, the wheelchair, strollers and crutches can stuck in the ground. The ground should also be installed correctly; otherwise even the best material has no chances to protect playing children.

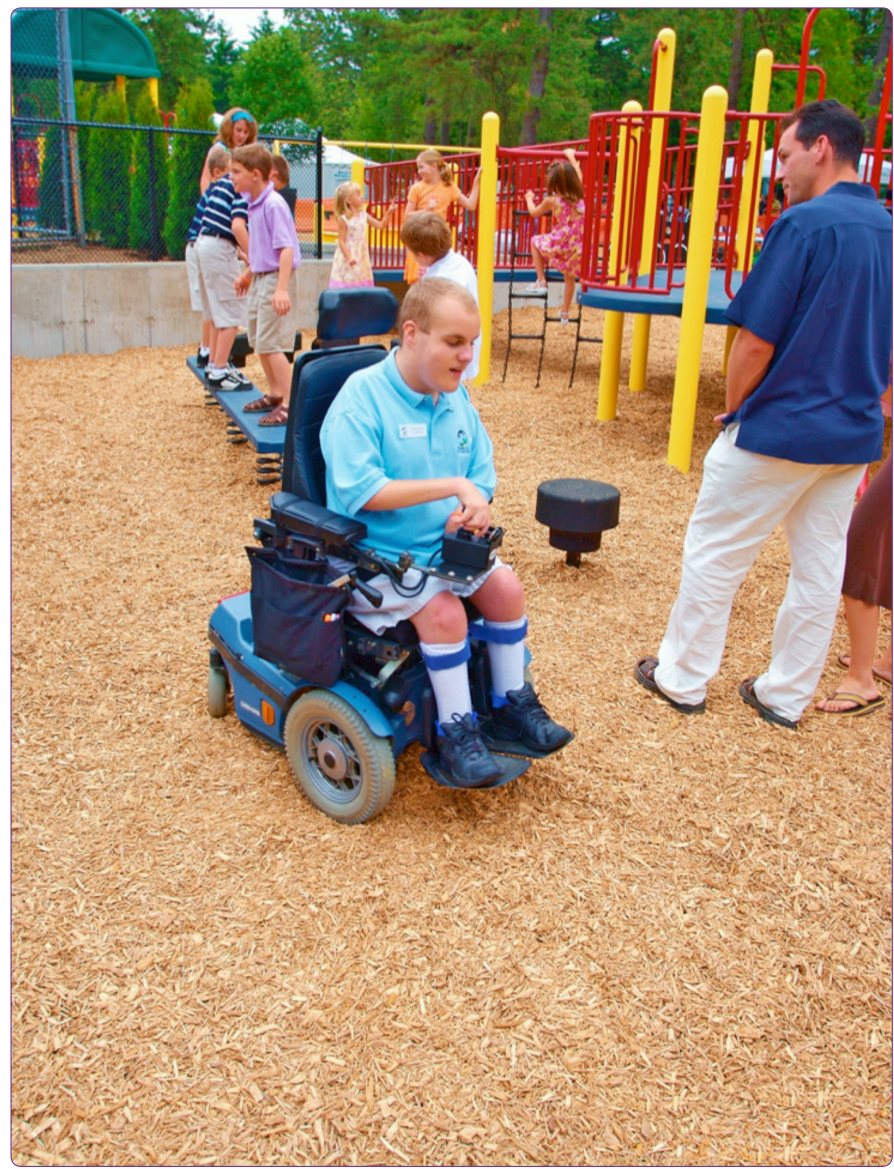

Figure 4. Engineered wood fiber. 
Table 1. The properties of possible ground materials developed. Based on Luke Whittaker "Best Groundcover Options for Playgrounds and Play Areas"

\begin{tabular}{|c|c|c|}
\hline Ground Material & Advantages & Disadvantages \\
\hline \multirow[t]{3}{*}{ Pea Gravel } & - natural look & - no protection for fallings \\
\hline & - attractive price & - choking hazard \\
\hline & & - wheels can get stuck in it \\
\hline \multirow[t]{3}{*}{ Rubber Mulch } & - shock absorbent & - dirty after long-term use \\
\hline & - low-maintenance & - escape area border \\
\hline & & - may smell in hot temperatures \\
\hline \multirow[t]{5}{*}{ Poured Rubber Rubber Tiles } & - slip resistant & - very expensive \\
\hline & - shock absorbent & \\
\hline & - wide color range & \\
\hline & - provide surface for playing & \\
\hline & - accessible for wheelchairs and strollers & \\
\hline \multirow[t]{4}{*}{ Natural Grass } & - natural look & - high-maintenance \\
\hline & & - prone to pests and bacterial buildup \\
\hline & & - by watering it is easier to cause the rust on metal play sets \\
\hline & & - not easy-accessible for wheelchairs and strollers \\
\hline \multirow[t]{3}{*}{ Artificial Grass } & - low-maintenance comparing to natural grass & - installation is more expensive than natural grass \\
\hline & - accessible for wheelchairs and strollers & - needs to be occasionally rose and fluffed \\
\hline & - offers a softer cushion for rough play & \\
\hline \multirow[t]{3}{*}{ Play Sand } & - absorb falls (if is not shallow) & - needs to be refilled to avoid shallows \\
\hline & & - can bothers while and after playing \\
\hline & & - not accessible for wheelchairs and strollers \\
\hline \multirow[t]{4}{*}{ Wood Chips and Mulch } & - good visual appeal & - can mold \\
\hline & - color range & - make good habitat for insects \\
\hline & & - choking hazard \\
\hline & & - needs regular refreshing \\
\hline \multirow[t]{5}{*}{ Engineered Wood Fiber } & - slip-resistant & - needs refilling \\
\hline & - shock absorbent & - quite expensive \\
\hline & - good appeal & \\
\hline & - biodegrade & \\
\hline & - accessible for wheelchairs and strollers & \\
\hline
\end{tabular}

\section{Playground Equipment}

While designing playground equipment, the designer needs to think about education and skills that every child needs, along his development process. It is important to develop personal skills of a child, who is expanding his or her personality and is trying to deal with surrounding by observing other's behavior. If on the playground there is a lot of equipment that require more than one user, children are encouraged to play together. They can learn to cooperate in the group, what is very important, especially for children with reduced intellectual and social skills. While playing, children improve physically by running, crawling and pulling. At the same time, they discover new abilities, expand their imagination and search for new solutions for the problems.
Children are easily bored if the playground environment provides few opportunities for them to engage in activities they enjoy, As Groves \& Mason (1993) found children prefer playgrounds which offer a variety of activities and which allow them to change, adapt and manipulate the setting. Titman's (1994) research showed that children liked a playground to have trees, leaves, shady areas, grassy areas and different levels, they wanted places where they could climb explore, take risks, build cubbies. They love to play with mud, soil, water and sand. 'The most popular equipment was that which allowed them to adapt it, to make new meanings around it and subvert or change its apparent intention. The greater-the potential of the equipment or item to be changed or manipulated the better' (Titman, 1994) (Figure 5). 


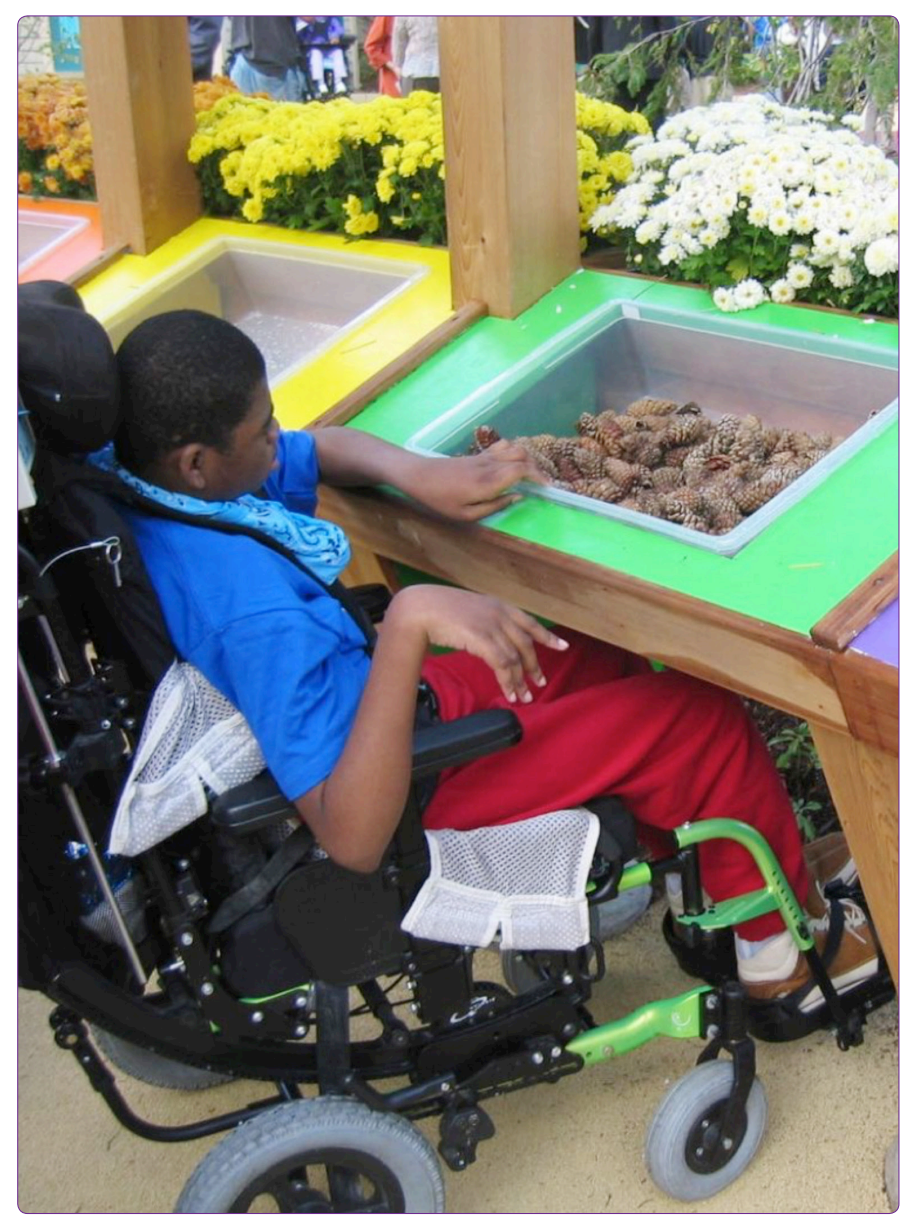

Figure 5. Sensory garden.

Playing outside helps the children to learn and understand natural habitat. They are interested in new phenomenon, schemas of working things they are discovering. In natural habitat, especially when the playground is surrounded by a wide range of flowers and plants children with sight loss can additionally stimulate their senses. They have the opportunity to improve their hearing skills by playing with music equipment. By this chance, in friendly environment they can learn how to recognize distance and the probable size of objects. By practicing rhythms, tact and melodies, children have a better start while learning new languages, mathematics and grammatical structures (Figure 6).

Slides can be fun, however the selection and their localization on the playground is important to prevent injuries. Also a cushion or other shock absorbent materials are needed on the landing place and its surrounding. Slides do not need to be straight, waving or spiraling their shape makes them more interesting and challenging. Also, installing small rollers on the place of slide side maximizes the sensory input (Figure 7).

Swing is one of the favorite equipments to play. Unfortunately, the injuries caused while playing are common.

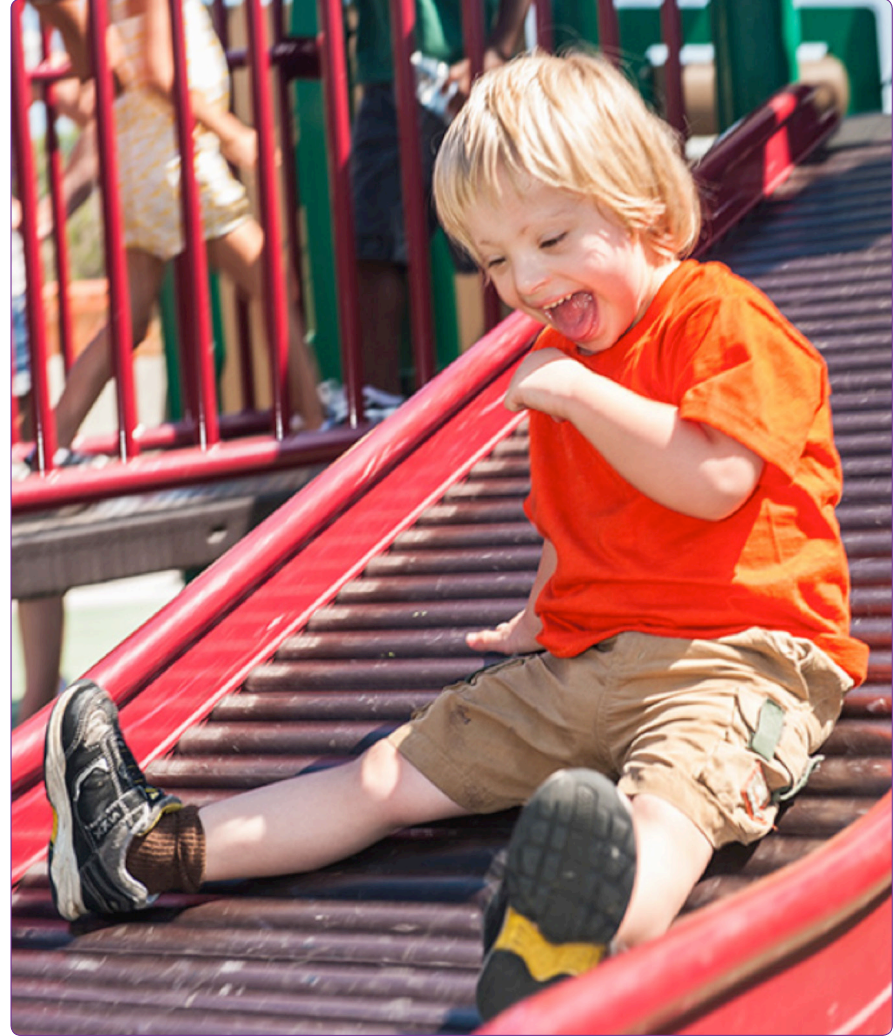

Figure 6 . A rollerslide.

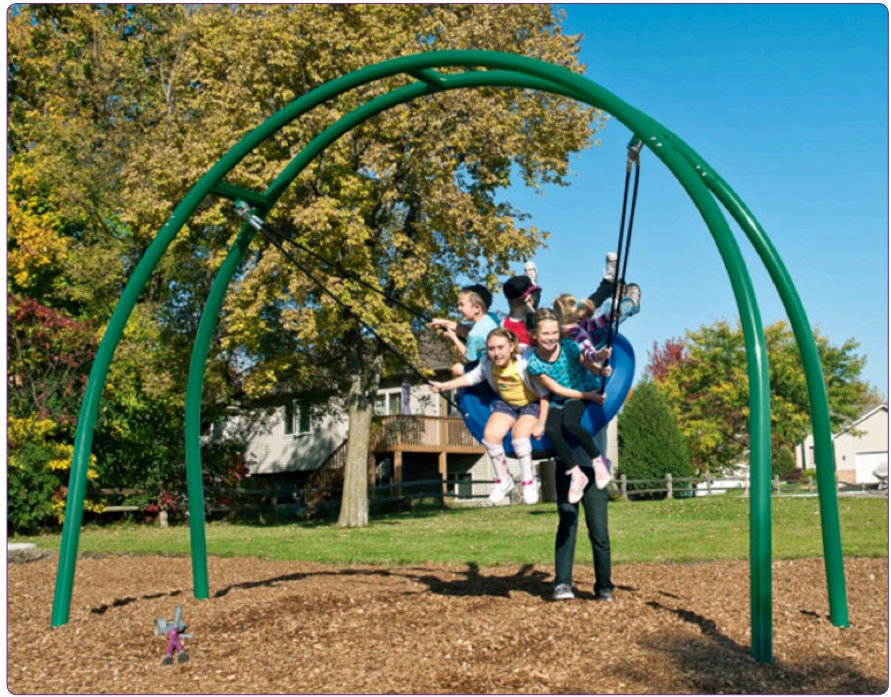

Figure 7. Oodle ${ }^{\circledast}$ Swing. Every child can swing on it.

Above all, their location in the playground needs to be proper to prevent accidents. Swing should be located in a distance to any other equipment. Children should have space to swing freely. During the play they cannot see what is happening behind their back and are also limited in changing their direction of moving. Proper localization also reduces the accidents where the inattentive child runs to the other equipment situated too close.

The image of the basic that is a plank hanging on the lines, cannot be used by little children and the ones who 
have muscle problems. Swing which corresponds to the universal design principles needs to have back support. A solution for the swings, which are available for everybody, can be "bed swings", which requires a lying position while playing (Figure 8).

A swing worth to notice is a Freedom Swing designed by Wayne Devine from Australia. This swing allows disabled children to use it without leaving their wheelchairs. The Australian made Liberty Swing is a wheelchair swing that safely allows for a maximum swing height and is fully lockable when not in use. The swing frame is constructed of high grade powder coated steel. A seat belt adds protection and security, and can be locked away in a box after each use (Figure 9).

Changes in the design took place not only in swings' appearance, also in see-saws. A traditional see-saw is suitable for two children, while there are other designs that are accessible for four to five persons. Additionally, the see-saws can be accessible for wheelchair users that give opportunities for shared play. With the properties like gentle rocking and profiled seats, also children with reduced mobility can use it (Figure 10).

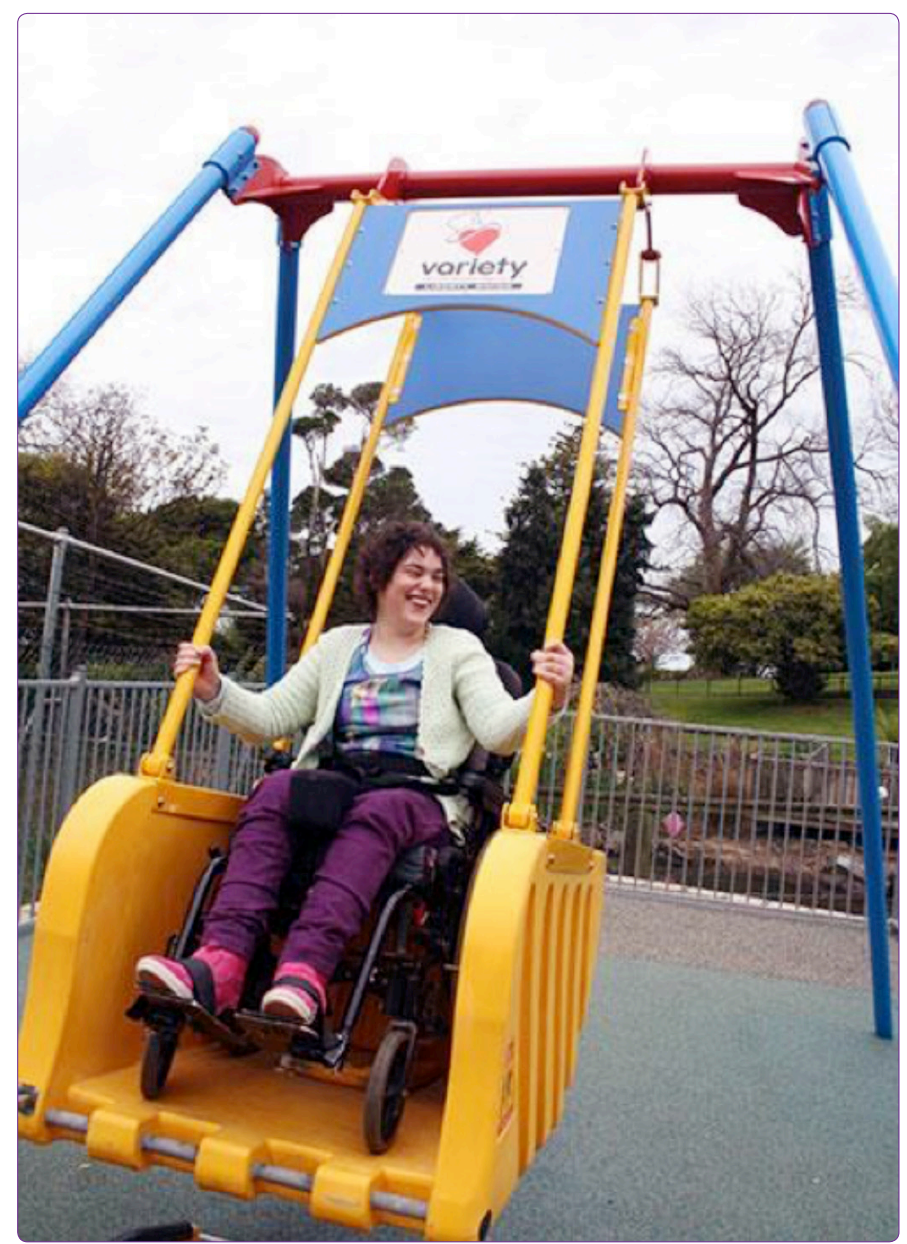

Figure 8. Liberty swing.

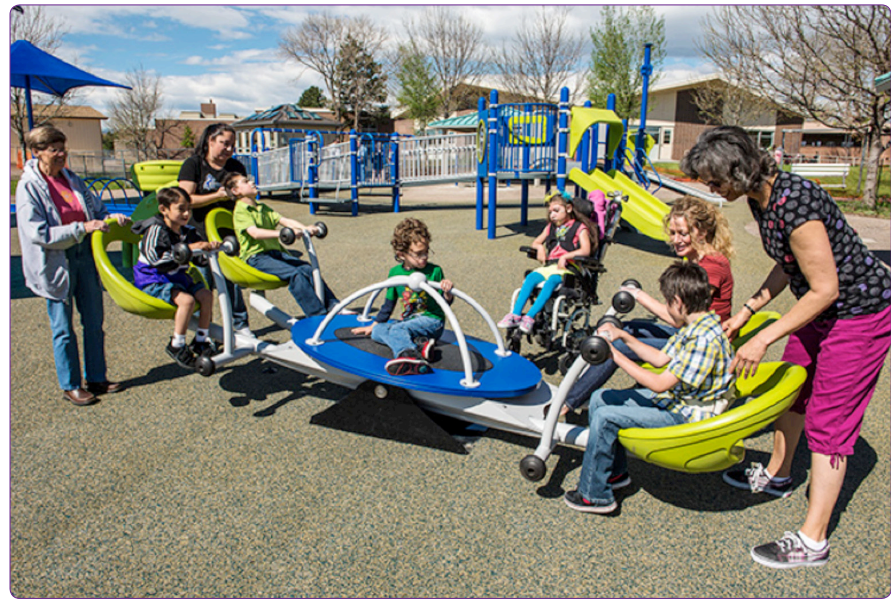

Figure 9. We-saw ${ }^{\mathrm{TM}}$ is an accessible version of a see-saw.

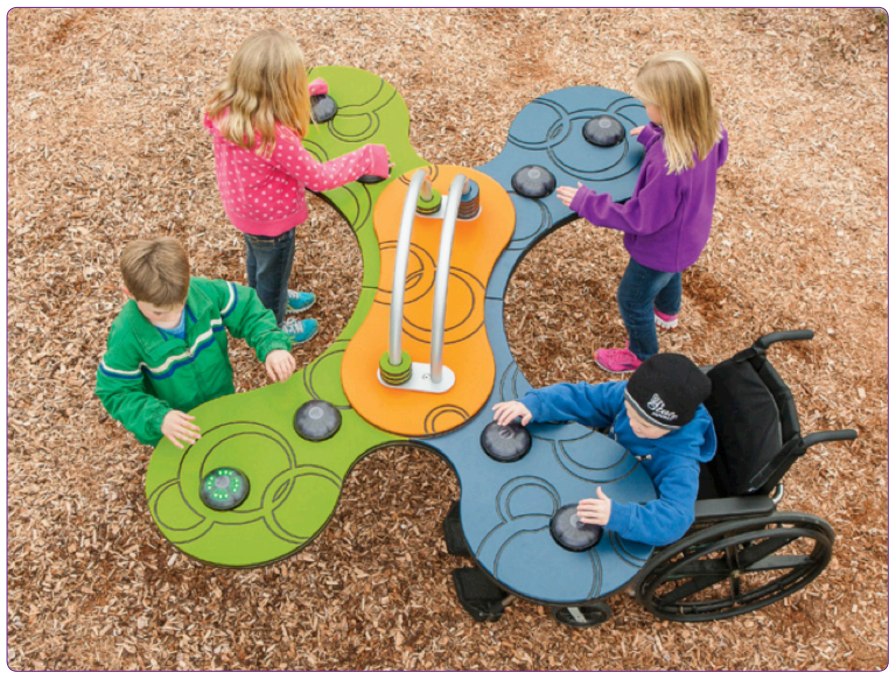

Figure 10. Pulse $^{\mathrm{TM}}$ Table Tennis.

While designing fully accessible playgrounds, using only traditional equipment is not sufficient. Using electronic equipment can be priceless for children with sight and hear impairment. Interactive and multisensory outdoor equipment which children can hear, see and touch makes it available for everyone regardless their mobility, autism or other learning abilities. Owing to the stimulation of these three senses, this devices helps to develop coordination and fast reacting skills while playing. Game stations resemble parking meter stands but have the kind of game show buzzer-bubbles that contestants love to slap. Each post is waterproof, lights up, plays music, bleeps, oinks and emits colorful swirls of LED lights in response to an opponent's speedy touch as Depass (2013) says. These devices encourage children to be active and develop hand-eye coordination.

\section{Materials and Colors of Equipment}

When choosing the equipment for the playground, the most important issue is children's safety. Materials also 
need to have great durability and resistant finish. Colors have a great impact on children's imagination and their explorations of the environment.

Wood, steel, plastic, chains and ropes are the most common materials used on the playgrounds. All of them have advantages and disadvantages, which are presented in the table below (Table 2). Stainless steel and plastics are the most preferred materials for slide surfaces. Although stainless steel is durable, it becomes extremely hot in direct sunlight and can cause second degree burns. On the other hand, this kind of material constitutes important risk factors with its razor sharp edges. (Metin, 2003)

Metal parts can be made of steel or aluminum. Both are strong and long lasting materials which provide a great variety of options while combining simple parts. However, metal parts are hard in touch and if they are not secured enough, may lead to serious injuries. For protection purposes, paints, rubbers and coats can be used. Steel needs to be protected against rust with ecological and childrensafe ingredients.

Table 2. Advantages and disadvantages of materials used for playground equipment; taken with slight changes from Wardle F., 1997

\begin{tabular}{|c|c|c|}
\hline Materials & Advantages & Disadvantages \\
\hline $\begin{array}{l}\text { Wood } \\
\text { (CCA Pine/Redwood) }\end{array}$ & $\begin{array}{l}\text { - Easy to use. Well suited to } \\
\text { Volunteers constructing playground. } \\
\text { - Looks natural. } \\
\text { - Easy to repair. } \\
\text { - Easy to attach elements to it. (e.g. slides, } \\
\text { handles, climbers) } \\
\text { - Inexpensive. } \\
\text { - Can be creative and design what you need. }\end{array}$ & $\begin{array}{l}\text { - Splinters, cracks, and splits.. } \\
\text { - Can burn. } \\
\text { - Lots of maintenance. } \\
\text { - Does not last as long as other materials. } \\
\text { - Does not look as upscale or classy. } \\
\text { - Some claim that the CCA process is hazardous } \\
\text { for children. }\end{array}$ \\
\hline $\begin{array}{l}\text { Laminated Plywood } \\
\text { (painted commercially) }\end{array}$ & $\begin{array}{l}\text { - Very colorful. } \\
\text { - Allows for designs with lots of flat surfaces. } \\
\text { - Easier to use for infant / toddler pieces. } \\
\text { - Can be repaired. } \\
\text { - A natural material that lasts. }\end{array}$ & $\begin{array}{l}\text { - Can chip and deteriorate quicker than plastic and metal. } \\
\text { - Restricted to flat designs. } \\
\text { - Expensive. } \\
\text { - Not appropriate unless bright colors are wanted. }\end{array}$ \\
\hline Polyethylene & $\begin{array}{l}\text { - Does not get hot. } \\
\text { - Has no splinters. } \\
\text { - Initially bright and attractive. } \\
\text { - Shapes that are safe. (e.g., a curved slide) } \\
\text { - Not structurally strong but usually used with } \\
\text { metal. } \\
\text { - Smooth and friendly to hold. }\end{array}$ & $\begin{array}{l}\text { - Colors fade over time. } \\
\text { - Overuse makes the playground look shoddy. } \\
\text { - Expensive. } \\
\text { - Limited number of uses and possibilities. }\end{array}$ \\
\hline $\begin{array}{l}\text { Steel or Aluminum } \\
\text { (coated, painted, or } \\
\text { untreated) }\end{array}$ & $\begin{array}{l}\text { - Strong. } \\
\text { - Lasts a long time. } \\
\text { - A large choice of paint colors. } \\
\text { - Unitized to provide a variety of options. } \\
\text { - Resists vandalism. } \\
\text { - Good for structural strength. }\end{array}$ & $\begin{array}{l}\text { - Slides can be very hot; posts / railings also get hot. } \\
\text { - Hurts to fall against. } \\
\text { - Almost impossible to repair. } \\
\text { - Cannot add to as wanted. } \\
\text { - Expensive. }\end{array}$ \\
\hline Fabrics & $\begin{array}{l}\text { - Light weight for roofs and canopies. } \\
\text { - Easy to replace. } \\
\text { - Shade is becoming a more critical issue on } \\
\text { playgrounds. }\end{array}$ & $\begin{array}{l}\text { - Soon fades and gets dirty. } \\
\text { - Tears easily. } \\
\text { - Flies in the wind. } \\
\text { - Tends to look shabby. } \\
\text { - No structural strength. }\end{array}$ \\
\hline "Recycled" Plastics & $\begin{array}{l}\text { - Looks like wood. } \\
\text { - Has some similar properties to wood. } \\
\text { - Can be cut and drilled. No splinters. } \\
\text { - Doesn't rot, rust, or split. } \\
\text { - Is made from recycled materials. }\end{array}$ & $\begin{array}{l}\text { - Has no structural integrity. } \\
\text { - Cannot be recycled into other plastics. } \\
\text { - Doesn't hold nails, screws, and lug bolts as well as } \\
\text { wood does. }\end{array}$ \\
\hline
\end{tabular}




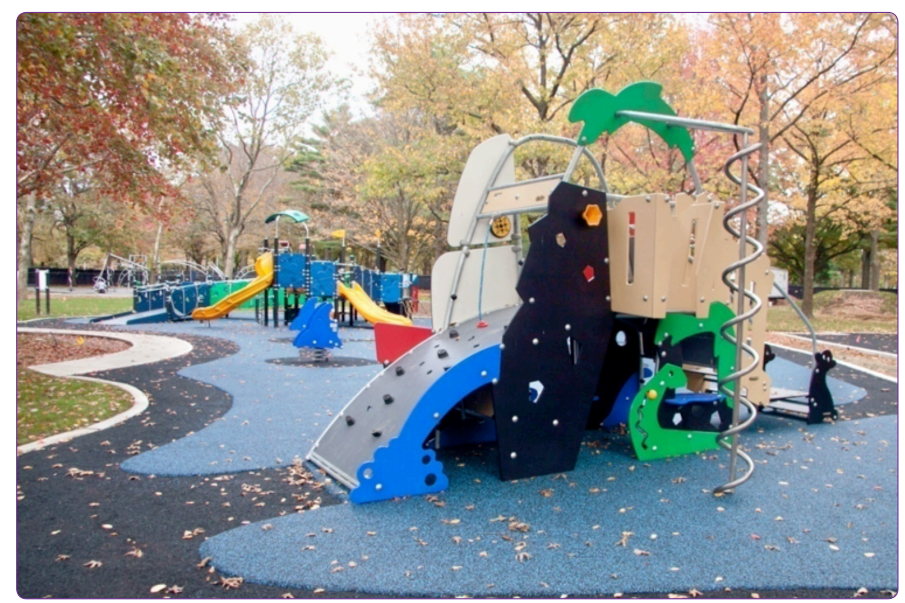

Figure 11. Playground with mixed materials.

Wood is one of the most common materials used for playground equipment. There are a number of advantages to be mentioned: it is easy to use and repair, it is natural, it can be designed into many shapes and the elements are easy to connect with each other. Unfortunately, there are some disadvantages too. Wood, can crack and splits into parts and does not last as long as other materials. It is highly important to notice what impregnating materials are used to protect the wood. In 2001, U.S. Consumer Product Safety Commission (CPSC) was petitioned by the Environmental Working Group (EWG) and Healthy Building Network (HBN) to enact a ban of CCA-treated wood for use in playground equipment and review the safety of CCA-treated wood for general use. Creosote-treated wood (e.g., railroad ties, telephone poles, etc.) are also prohibited because of the health threat.

Plastics (polyethylene) and recycled plastics are popular materials used to make playground equipment. Recycled plastics are common especially among societies who are concerned about ecological issues. Unfortunately, as Wardle (1997) indicates: while part of these plastics is recycled from waste products, these playgrounds cannot themselves be recycled. Further, most recycled plastic does not have the structural strength of wood or metal (Figure 11).

It is worth to remember that all the parts of the equipment need to be installed by authorized staff that follows the manual of the objects. Good conservation is also a great factor while thinking about user's safety. While using neglected playground equipment the risk of the injury is far higher, than the one which is well maintained and in good condition.

Color plays a great role in children's life when they learn about the world. It is worth to think about it while designing a playground. Contrasting colors can make moving on the playground easier, by marking different sections in different colors it is possible to separate them visually. Using contrasting colors like yellow and blue will be interesting for children and make playground livelier. It is important especially for children with visual impairments. Unfortunately, children with Attention Deficit Hyperactivity Disorder (ADHD) may have problems with concentration while looking on yellow. This causes the need to use muted colors. The best solution is to compromise and strike a golden mean.

\section{Level Differences}

In order to enable children to play between different levels on the playground, it is common to use platforms, steps, ladders, guardrails and protective barriers. This equipment should protect children from falling down. The fall zone should be safe for children in case of an incident as well.

However, for children with disabilities, every level difference may result in minor or major problems. The best solution is, installing the equipment for activities on the floor level if possible. This enlarges the number of children who can play together with equal access.

Unfortunately, installing every part of the equipment on the same level may lower the attractiveness of the playground. It also can be unsatisfactory for children who enjoy climbing and observing the world from different height than their own. For the purpose to provide fun equally for every child, some ramps and platforms may be installed. In contrast to stairs and ladder, flat or slightly risen platforms are available for everyone. It should be covered by non-slippery surface and have openings providing drainage. ADA (Americans with Disabilities Act) report that the minimum width of the ramp should measure $92 \mathrm{~cm}$. Although this is a value measured for adults and there are children playing on the playground, the ramp should not be narrower. It is because, parents can also use a wheelchair and they need to be able to get to their child in every moment.

According to the U.S. Consumer Product Safety Commission, there are two schemes of vertical barriers protecting children against falling - guardrails and barriers. The difference between them and recommended heights are shown in the table below (Table 3).

Guardrails and barriers should be high enough to prevent the tallest children from falling over the top. For guardrails, the lower edge should be low enough so that the smallest children cannot walk under it. Barriers should be low enough to prevent the smallest child from getting under the barrier in any way. This is generally done by designing the barrier so that the small torso probe cannot pass under or through the barrier. Vertical infill for protective barriers may be preferable for younger children because the vertical components can be grasped at whatever height a child chooses as a handhold. (U.S. Consumer Product Safety Commission) 
Table 3. Guardrail and barrier recommendations from U.S. Consumer Product Safety Commission (redrawn and converted into metric system)

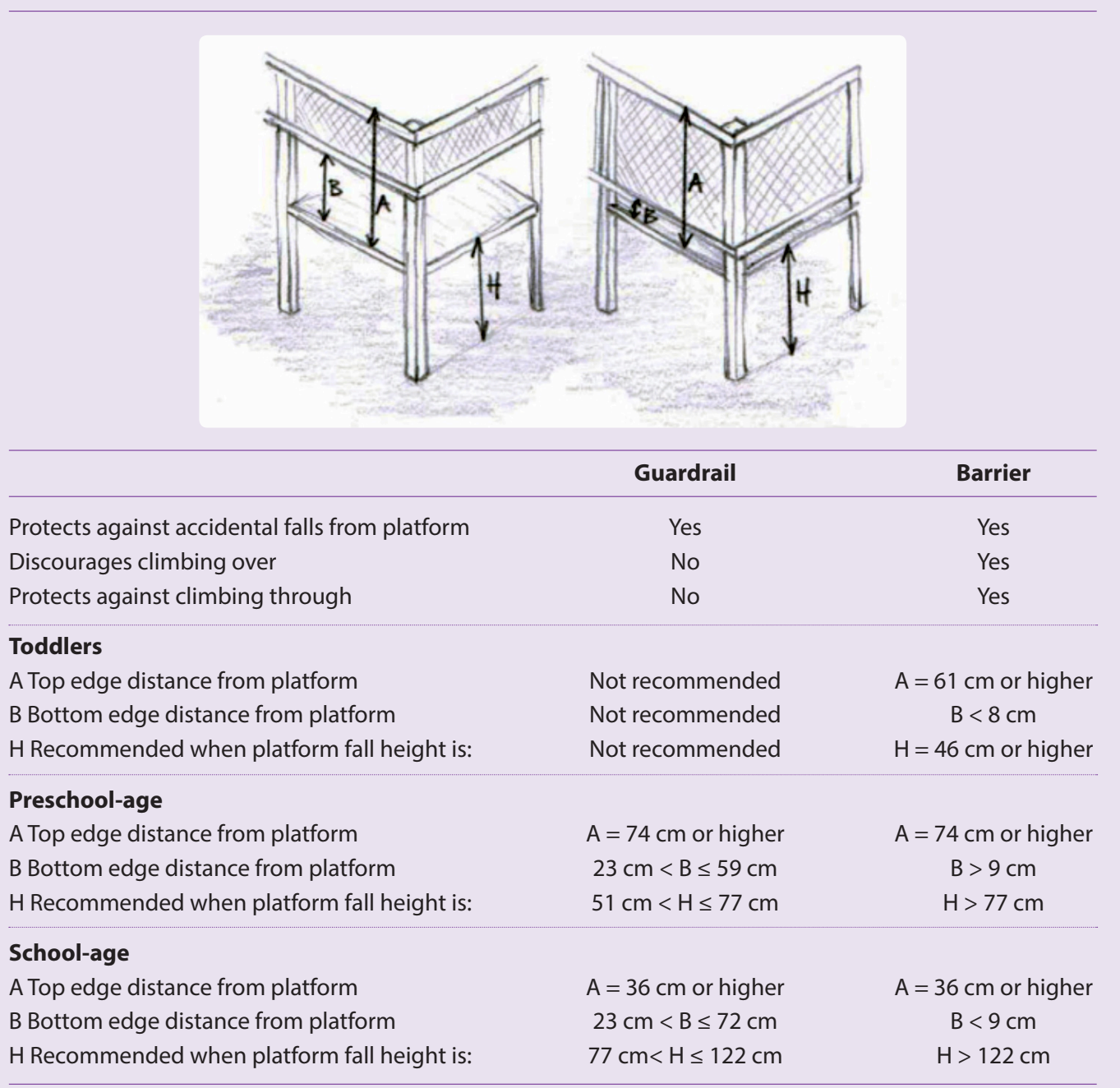

\section{Conclusion}

For the majority of the society, being a child is the most happy period of time, free of responsibilities and fun-filled. However, children who are disabled in any way, childhood can be a hard experience. If their disability is isolating them from shared play with their peers, they become lonely. This can affect their entire future adult lives, because of the lacks in communication and interpersonal skills as well as physical development.

While designing a playground, it is important to think about each child, not only about a group of them, who are considered as "healthy". There are several essential issues that cannot be omitted. Firstly, the playground equipment should be chosen wisely, with a wide range of physical exercises, so every child can benefit, at least partly, if is not able to use every piece of it.

A model playground, even with the newest and most accurate equipment will not be suitable if the ground and ramps will not be fully accessible. Every material has its advantages and disadvantages as they are described in this article. Designer's role is to choose a material which suits the requirements the most and use it in a correct and safe manner. Materials and colors should also be selected with reasonable accuracy. Level differences should be secured and wide enough to meet requirements for the assistance devices like wheelchairs which vary from country to country.

For future studies, a case study can be conducted using the recommendations in this paper. The suggestions should be evaluated by the user as another study related to this proposal in the future. The feedback that will be obtained from the trial of the proposed model will be helpful to develop the model more. A playground model proposal that is evolving from the fundamentals given in this paper will be then possible for putting into practice and bring new developments in the area. Better playgrounds are the ones where everybody can play. 


\section{References}

Ahıskalı, S. Ö., Çocuk oyun alanlarında döşeme. Peyzaj Mimarlığı Dergisi. T.M.M.O.B. Peyzaj Mimarları Odası, İstanbul Şubesi, Temmuz-Ağustos, 5(14), İstanbul, 1998.

Aksoy, Y., Çocuk Oyun Alanları Üzerine Bir Araştırma İstanbul, Isparta, Eskişehir, Erzurum, Kayseri, Ankara, Zonguldak ve Trabzon illeri örneği, İstanbul Aydın Üniversitesi Fen Bilimleri Dergisi, 3(6), 82-106, 2011.

Algan, H. ve Uslu, C. (). Illköğretim Okul Bahçelerinin Tasarlanmasına Paydaş Katılımı: Adana Örneği. Akdeniz Üniversitesi Ziraat Fakültesi Dergisi. 22(2):129-140, 2009.

Depass D., "Multisensory Playgrounds Accessible to Kids with Disabilities" SpecialEdPost, News for the special education community. February 2013. Retrived from: http://specialedpost.org/?p=23441 [Accessed 4 January 2015].

Evans J., "In Search of Peaceful Playgrounds" Education Research and Perspectives, Vol.28, No.I, 2001, page 55, Deakin University.

Landscape Structures, "Playground Inspirations Book" Virtual Catalogs and Inspirations Retrieved from: http://www.playlsi. com/ [Accessed 4 January 2015].

Miraca U. M. G., "The "Me" Behind the Mask: Intellectually Gifted Students and the Search for Identity" Supporting Emotional Needs of the Gifted, Citation From Roeper Review. 1998 Feb 20(3). Retrieved from: https://sengifted.org/archives/articles/the-me-behind-the-mask-intellectually-gifted-students-and-the-search-for-identity [Accessed 2 March 2015].

National Institute of Mental Health, "What Is Autism Spectrum Disorder?" National Institute of Mental Health Retrieved from: http://www.nimh.nih.gov/health/topics/autism-spectrum-disorders-asd/index.shtml\#part3 [Accessed 4 January 2015].

Palisano J R. PT ScD, Professor, "Effect of environmental setting on mobility methods of children with cerebral palsy" Developmental Medicine \& Child Neurology 2003, Drexel University. Retrieved from: http://onlinelibrary.wiley.com/ doi/10.1111/j.1469-8749.2003.tb00914.x/pdf [Accessed 4 January 2015].

Pinar M., "The Effects Of Traditional Playground Equipment Design In Children's Developmental Needs", A Thesis Submitted to The Graduate School of Natural and Applied Sciences of The Middle East Technical University, July 2003.

Skulski J., "Planning for Inclusion. Implementing an Accessibility Management Program in a Parks and Recreation Business Model" National Center on Accessibility, Indiana UniversityBloomington, January 13, 2009. Retrieved from: http://www. ncaonline.org/resources/articles/planning.shtml [Accessed 5 January 2015].

Strickling C., "Impact Of Visual Impairment On Development", Texas School for the Blind and Visually Impaired. Retrieved from: http://www.tsbvi.edu/infants/134-infants/3293-theimpact-of-visual-impairment-on-development [Accessed 25 February 2015].

Titman W., "Special Places, Special People: The Hidden Curriculum of School Grounds", Learning Through Landscapes, England 1994.
Türkyılmaz, E., A Method to Analyze the Living Spaces of Wheelchair Users Using IFC, Procedia - Social and Behavioral Sciences, Volume 222, Pages 458-464, (2016).

U.S. Consumer Product Safety Commission, "Public Playground Safety Handbook" U.S. Consumer Product Safety Commission, Saving Lives and Keeping Families Safe. Publication \#325 (2010).

U.S. Consumer Product Safety Commission, Status Report on CCA Pressure-Treated Wood In Playground Equipment, Washington, D.C. 20207, USA 2002.

UniversalDesign.com, The Resource for Universal Design News, "Liberty Swing". Retrieved from: http://www.universaldesign.com/2012-06-11-16-52-25/assistive-technology/1302liberty-swing.html [Accessed 4 January 2015].

Wardle F., Ph.D., "Outdoor Play: Designing, Building, and Remodeling Playgrounds for Young Children" Early Childhood News, 1997. Retrieved from: http://www.earlychildhoodnews.com/ earlychildhood/article_view.aspx?ArticlelD=65, [Accessed 18 February 2015].

Whittaker L., "Best Groundcover Options for Playgrounds and Play Areas" INSTALL-IT-DIRECT. Retrieved from: http://www. installitdirect.com/blog/best-groundcover-options-for-playgrounds-and-play-areas-2/ [Accessed 4 January 2015].

Zimmermann R., "Universal Design Means Accessibility for One and All" Facilities Net, November 2006, Retrieved from: http://www.facilitiesnet.com/ada/article/Accessibility-forOne-and-All--5573 [Accessed 4 January 2015].

\section{Internet References}

Figure 1: http://togetherweplay.playlsi.com/category/autism

Figure 2: http://brooklynsplayground.org/see-the-playground (Redrawn from)

Figure 3: http://media.npr.org/assets/img/2013/08/21/playgrounds-3_custom-98e9d99f102a09b47dbecf221c86efa7968b6933-s1200.jpg

Figure 4: http://www.davidwilliamsassociates.com/sites/default/files/imagecache/product_full/ewf_accessible.jpg

Figure 5: http://www.play-scapes.com/wp-content/uploads/2010/02/carter-school-playground-boston 6756x1024.jpg

Figure 6: https://www.playlsi.com/globalassets/530-in-column/ inclusive-playsection/inclusive01_530.jpg?id=13367

Figure 7: https://www.playlsi.com/contentassets/9f2ba2d643cf424fb71e1d14b26fd8ca/ip-oodleswing_screen. jpg? $\mathrm{w}=530 \& \mathrm{~h}=450 \&$ mode $=\max$

Figure 8: http://www.burnie.net/files/ffe4dbed-3bb0-4bcca7b2-a27e00cfe9c6/jess.jpg

Figure 9: 9ttps://www.playlsi.com/contentassets/ 374b59c308ac449dad3a458075c127df/ip-we-saw-01_ screen.jpg?width $=905$ \&height $=450 \&$ mode $=\max$

Figure 10: https://www.playlsi.com/contentassets/769875c4c f97428791270f2b618de135/ip-pulse-table-tennis_screen. jpg? width $=905 \&$ height $=450 \&$ mode $=\max$

Figure 11: http://latcp.org/wp1/wp-content/uploads/2012/04/ October-28th-300x199.jpg 